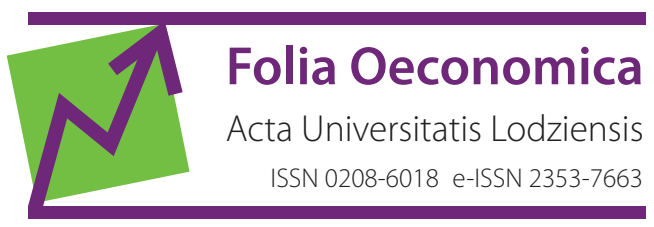

www.czasopisma.uni.lodz.pl/foe/

1(340) 2019

DOI: http://dx.doi.org/10.18778/0208-6018.340.05

\title{
Monika Klimontowicz
}

University of Economics in Katowice, Faculty of Finance and Accounting, Department of Banking and Financial Markets, mklimontowicz@ue.katowice.pl

\section{Janina Harasim}

University of Economics in Katowice, Faculty of Finance and Accounting, Department of Banking and Financial Markets, jharasim@ue.katowice.pl

\section{Mobile Technology as Part of Banks' Business Model}

\begin{abstract}
During the last few decades, the banking market has changed significantly making banks face new challenges. Mobile technology development has had a powerful impact on all human activities including banking. Mobile technology has changed both the information and communication sharing, as well as customers' market behaviour. All these changes should be taken into account in the process of searching for competitive advantage factors and designing banks' business models.

The purpose of the paper is to propose the framework for banks' business model that incorporates using mobile technology and creating a competitive advantage. The foundation of this framework is based on theoretical considerations. The paper analyses contemporary business models used by banks, their value proposals and their relation to customers' needs and expectations. The research highlights the routes for using mobile technology in the further development of banks' business models from the perspective of the process of creating and delivering value for customers.
\end{abstract}

Keywords: bank business model, mobile technology, customer-value, banking innovations JEL: G21, O33, D14 


\section{Introduction}

Today technology is one of the most significant factors influencing the shape of banking systems all over the world. Initially, banks' motivation to implement modern technology arose from the desire to improve the efficiency of different processes. It served to reduce costs (Delafrooz, Taleghani, Taghineghad, 2013; Persson, 2013) and increase the efficiency, speed, and control of customer-bank interactions (Honebein, Cammarono, 2006). The remote access to banking services and their self-management primarily delighted both customers and banks. The additional value of the overall customer experience stems from the fact that clients can access services when and where they want without the necessity of interpersonal contact (Blount, 2010). After the first period of technology admiration, retail banks realised that a large group of customers still preferred face-to-face interactions. Balancing the need concerning service functionality and an individual approach to customers focused on building relations remains a challenge for banks. In recent years, technological landscape has been enriched by mobile technology. Mobile technology development has had a powerful impact on all human activities including banking. Mobile technology has changed both the information and communication sharing, as well as customers' market behaviour. The dynamic growth of the number of smartphone users let them share information and access to any services in real time. Mobile phones have increasingly become tools that consumers use for banking, payments, budgeting, shopping and communication (especially by using social media). Social media development has influenced markets, companies, and institutions, as well as customers' behaviour and expectations (Ahlqvist et al., 2008; Mayfield, 2008; Kaplan, Heinlein, 2010; Hanna, Rohm, Crittenden, 2011; Weinberg, Pehlivan, 2011; Durkin, Mulholland, McCartan, 2015; Papagiannidis, Bourlakis, 2015). Banks have attempted to deploy mobile technology and social media in their market strategies to be more communicative, more customer-centric and innovative (Murray et al., 2014), but their impact on banks needs to be better assessed and understood. This paper argues that the extant research in the banking services area is underdeveloped in relation to furthering knowledge on the role of mobile technology in the process of creation, delivering and enhancing value for customers as a core part of business model. It fills this gap and contributes to the results of other research by analysing banks' business models, their value proposals, the correspondence of these value to customers' needs and expectations, and mobile technology usage.

The purpose of the paper is to propose the framework for banks' business model that incorporates mobile technology usage. The theoretical concept of the framework was based on an in-depth literature review and an analysis of banks' contemporary business models. The paper begins with a literature review concerning business models. It further discusses banks' contemporary business models, 
their value proposals, customers' needs and expectations, as well as mobile technology application in the retail banking market. The results of this exploratory analysis provided the basis for building the framework of banks' business model incorporating the usage of mobile technology.

\section{The theoretical foundations for business model designing - literature review}

A business model should enable gaining a competitive advantage over rivals and maintaining a desirable market position. It combines all internal tangible and intangible resources of a given firm that are the source of its strengths and weaknesses with all threats and opportunities that have arisen in the banking market.

An efficient business model is a long-term method of using resources in creating value for customers and other stakeholders (Magretta, 2002; Casadesus-Masanell, Ricart, 2007; Demil et al., 2015; Massa, Tucci, Afuah, 2017; Priem, Wenzel, Koch, 2018). A business model may be defined as a simplified way that explains the relation between internal and external factors that influence reaching a given organisation's objectives and value creation (Magretta, 2002; Zott, Amit, 2008; 2010; Santos, Spector, van der Heyden, 2009; Saebi, Foss, 2014; Birkinshaw, Ansari, 2015; Wieland, Vargo, Hartmann, 2017). It is a philosophy of a given organisation's market activity and a conceptual tool expressing its business logic (Nosowski, 2010; 2012; Teece, 2010; Ritter, 2014; Wirtz et al., 2016; Evans et al., 2017), precisely determining the strategic assumptions of value creation (Pyka, 2013). A business model may also be defined by describing particular types of components with common characteristics. The review of business model definitions and components (see Table 1) allows us to state that the ability to create and deliver the original value proposition for customers is its core foundation. This item reflects firms' ability to fulfil customers' needs and expectations and match firms' products and services with these requirements. Among other elements, authors usually indicate the importance of defined market segments of customers, tangible and strategic resources, and strategic processes, including the way of communicating and delivering value to customers. It is important to realise that there is not just one effective business model. Specific contexts, such as different organisational environments and strategies for added value, may lead to different forms of effective business models (Jansen, Steenbakker, Jägers, 2017). 
Table 1. Definitions and components of business models in selected concepts

\begin{tabular}{|c|c|c|}
\hline Author & Definition & $\begin{array}{c}\text { The Components of Business } \\
\text { Model }\end{array}$ \\
\hline Zott, Amit (2001) & $\begin{array}{l}\text { The content, structure, and governance } \\
\text { of transactions designed to create value } \\
\text { through the exploitation of business } \\
\text { opportunities. }\end{array}$ & $\begin{array}{l}\text { Transaction content, } \\
\text { transaction structure, } \\
\text { transaction governance. }\end{array}$ \\
\hline Magretta (2002) & $\begin{array}{l}\text { Stories that explain how enterprises } \\
\text { work; a good business model answers } \\
\text { Peter Drucker's age-old questions: Who } \\
\text { is the customer? Moreover, what does } \\
\text { the customer value? It also answers the } \\
\text { fundamental questions every manager } \\
\text { must ask: How do we make money in this } \\
\text { business?, What is the underlying economic } \\
\text { logic that explains how we can deliver value } \\
\text { to customers at an appropriate cost? }\end{array}$ & $\begin{array}{l}\text { Customer definition, value } \\
\text { to customer, revenue and } \\
\text { economic logic. }\end{array}$ \\
\hline $\begin{array}{l}\text { Dubosson- } \\
\text {-Torbay, } \\
\text { Osterwalder, } \\
\text { Pigneur (2002) }\end{array}$ & $\begin{array}{l}\text { The architecture of a firm and its network } \\
\text { of partners for creating, marketing and } \\
\text { delivering value and relationship capital } \\
\text { to one or several segments of customers } \\
\text { to generate profitable and sustainable } \\
\text { revenue streams. }\end{array}$ & $\begin{array}{l}\text { Products, customer } \\
\text { relationship, infrastructure } \\
\text { and network of partners, and } \\
\text { financial aspects. }\end{array}$ \\
\hline $\begin{array}{l}\text { Morris, Schin- } \\
\text { dehutte, Allen } \\
(2005)\end{array}$ & $\begin{array}{l}\text { A concise representation of how } \\
\text { an interrelated set of decision variables } \\
\text { in the areas of venture strategy, } \\
\text { architecture, and economics are addressed } \\
\text { to create a sustainable competitive } \\
\text { advantage in defined markets. }\end{array}$ & $\begin{array}{l}\text { Value proposition, customer, } \\
\text { internal processes/ } \\
\text { competencies, external } \\
\text { positioning, economic model, } \\
\text { and personal/investor factors. }\end{array}$ \\
\hline $\begin{array}{l}\text { Shafer, Smith, } \\
\text { Linder (2005) }\end{array}$ & $\begin{array}{l}\text { A representation of a firm's underlying core } \\
\text { logic and strategic choices for creating and } \\
\text { capturing value within a value network. }\end{array}$ & $\begin{array}{l}\text { Strategic choices, create value, } \\
\text { capture value, value network. }\end{array}$ \\
\hline $\begin{array}{l}\text { Osterwalder, } \\
\text { Pigneur (2005) }\end{array}$ & $\begin{array}{l}\text { The blueprint of how a company does } \\
\text { business. }\end{array}$ & $\begin{array}{l}\text { Value proposition, target } \\
\text { customer, distribution } \\
\text { channel, relationship, } \\
\text { value configuration, core } \\
\text { competency, partner network, } \\
\text { cost structure, revenue model. }\end{array}$ \\
\hline $\begin{array}{l}\text { Johnson, } \\
\text { Christensen, } \\
\text { Kagermann } \\
(2008)\end{array}$ & $\begin{array}{l}\text { A business modelconsists of four } \\
\text { interlocking elements, that, taken together, } \\
\text { create and deliver value. }\end{array}$ & $\begin{array}{l}\text { Customer value proposition, } \\
\text { profit formula, key resources, } \\
\text { key processes. }\end{array}$ \\
\hline Teece (2018) & $\begin{array}{l}\text { A business model describes an architecture } \\
\text { for how a firm creates and delivers value } \\
\text { to customers and the mechanisms employed } \\
\text { to capture a share of that value. }\end{array}$ & $\begin{array}{l}\text { Set of elements encompassing } \\
\text { the flows of costs, revenues, } \\
\text { and profits. }\end{array}$ \\
\hline
\end{tabular}

Source: authors' own elaboration based on Zott, Amit, Massa, 2011; Teece, 2018 
All components of the presented business models can be grouped into the following core areas (Ballon, 2007; Osterwalder, Pigneur, 2005): creating value for customer, building relations with customers, influencing customers' satisfaction, loyalty, and engagement, delivering value by proper infrastructure, managing costs and revenues of the areas mentioned above. These areas constitute the business model canvas (see Figure 1).

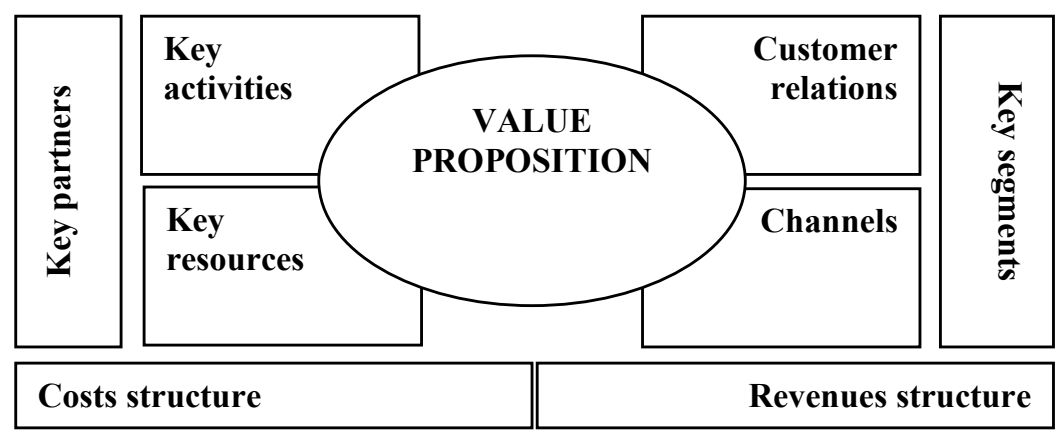

Figure 1. The business model canvas

Source: Osterwalder, Pigneur, 2005

The fields of the business model and their components should be considered as a potential means through which banks can fulfil their objectives and gain outcomes such as financial performance, risk profile, and contribution to financial stability as well as the economy which can change over time. Searching for a competitive advantage requires analysing these components from the perspective of their potential to create value for customers (Deloitte, 2012). The process of business model creation should thus be based on the knowledge concerning customers' market behaviour, habits, needs, and expectations.

\section{Value Proposals in Banks' Business Model and Its Correspondence to Customers' Needs and Expectations}

Banks' business models have evolved over the last few decades. The traditional business models that divided banks into universal and specialised ones focused on the range of products and services offered to customers. The next generation of banks' business models has followed up and developed the value proposals of previous ones. They have tried to combine products and services with selected needs and expectations of leading customers (Capgemini, 2008). Their value proposition includes products and processes (see Table 2). 
Table 2. The value proposition in banks' business models

\begin{tabular}{|c|l|l|}
\hline \multicolumn{2}{|c|}{ Banks' Business Model } & \multicolumn{1}{c|}{ Value Proposition } \\
\hline \multirow{4}{*}{$\begin{array}{c}\text { Tradi- } \\
\text { tional }\end{array}$} & Universal bank & $\begin{array}{l}\text { Offering a wide range of products (not customised) for different } \\
\text { customer segments. }\end{array}$ \\
\cline { 2 - 3 } & Specialised bank & $\begin{array}{l}\text { Offering a narrow range of products dedicated to selected } \\
\text { customers' needs such as mortgages, car purchases, etc. }\end{array}$ \\
\hline \multirow{4}{*}{$\begin{array}{c}\text { Contem- } \\
\text { porary }\end{array}$} & $\begin{array}{l}\text { Financial advisor } \\
\text { for mass affluent } \\
\text { customers }\end{array}$ & $\begin{array}{l}\text { Niche positioning leveraged by delegated marketing promotion. } \\
\text { The main strength is the confidence relationship with the brand, } \\
\text { with a strong feeling of belonging. }\end{array}$ \\
\cline { 2 - 4 } & $\begin{array}{l}\text { Dommunity bank } \\
\text { model }\end{array}$ & $\begin{array}{l}\text { Specialised service provider to a specific community (travellers, } \\
\text { military, migrants). Closest to personal affinity, recognised } \\
\text { by “buzz" network. }\end{array}$ \\
\cline { 2 - 4 } & $\begin{array}{l}\text { Trust operator } \\
\text { model }\end{array}$ & $\begin{array}{l}\text { The most economic without minimising security or quality. } \\
\text { The lowest prices on the market. }\end{array}$ \\
\hline $\begin{array}{l}\text { One-stop shopping for customers, including all kinds of personal } \\
\text { or family services: domestic chores, bills management, } \\
\text { employment research, real estate, mobile phones, journeys, } \\
\text { sports and other tickets. }\end{array}$ \\
\hline
\end{tabular}

Source: authors' own elaboration

Banks' business models are also divided taking into account the financial perspective and a given bank's position in the market. Such a taxonomy is based on core bank processes and usually includes the following variables: acquisition of funds for operations, service and product provision as a means to generate revenues, as well as risk-taking (Roengpitya, Tarashev, Tsatsaronis, 2014; Thomkus, 2014; Ayadi et al., 2016; Framé, Vouldis, 2017). In this case, banks are divided into retail-funded commercial banks, wholesale-funded commercial banks, and capital markets-oriented banks. Based on statistical analysis of financial data, the European Central Bank study distinguishes four categories of banks' business models (Framé, Vouldis, 2017):

1) wholesale funded banks - large banks whose asset side consists mostly of loans, they rely much more than other types of banks on debt for their funding and less on household deposits, they are characterised by far the most extensive use of derivatives, both for hedging and trading;

2) securities holding banks - they have a relatively large securities portfolio and cash buffer, fund themselves with deposits and do not use derivatives much; they are usually small, but this cluster is the most heterogeneous cluster as regards their size;

3) traditional commercial banks - they are medium-sized, have more loans on their asset side than all other banks, fund themselves mostly with deposits and use derivatives primarily for hedging;

4) complex commercial banks - medium-sized banks that possess a significant percentage of loans on their asset side but lower compared to tradition- 
al ones because they also own securities to a larger extent, fund themselves mostly with deposits (but less than traditional banks) and use derivatives mostly for trading purposes; the category is a hybrid one, between wholesale funded and traditional banks. This taxonomy is made from the bank perspective and does not take into account customers' needs and expectations. As already recognised, such a perspective is not enough in recent years for building a competitive advantage (Accenture, 2012). It is especially important in the digital disruption era when some predictions assume the disappearing of half of the worlds' banks as a result of the economy's digital transformation (Martino, Schaffner, 2015). Digital transformation is a huge opportunity for the banking sector as it may help banks in customer acquisition and retention as well as revenue generation. Increasing competition and decreasing customer loyalty have made customer relationship management very useful for banks. Banks need to earn the highest level of trust to retain existing customers, acquire new ones, create genuine loyalty, and maximise customer lifetime value. Digital technologies will help banks to provide knowledge concerning customers and target them with customised products and communications remotely all day (Ernst \& Young, 2015). The importance of being easy, credible and secure in order to keep existing customers and acquire new ones has become fundamental to banks (Thalassinos, 2008; Thalassinos, Venediktova, Staneva-Petkova, 2013). Reducing the gap between customers' expectations and delivered services will enhance customers' loyalty and banks' profitability (Thalassinos, Venediktova, Staneva-Petkova, 2013). Preparing the adequate value proposition should incorporate knowledge of customers' core values, technology usage, a preferred way of communication, as well as financial needs and expectations.

Additionally, the buying behaviour results from different expectations, experiences, generational history, lifestyles, values, and demographics (Klimontowicz, Harasim, 2017). Those factors differ among generations. A business model must take into account the needs and expectations of customers' segments. Today they consist of representatives of Generation X, Generation Y, and Generation Z (see Table 3).

Representatives of Generation X still prefer in-person branch banking and face-to-face consulting services, but they are open to online and mobile banking. However, they will expect a high degree of personalisation in their digital banking experience. Generations $\mathrm{Y}$ and $\mathrm{Z}$ adopt mobile banking easily. As a transaction-rich segment, Generation $\mathrm{Z}$ should be treated as a significant customer segment for mobile banking (Arnfield, 2015; 2016). Regardless of their generation, customers have a core set of requirements that are unlikely to change over the next few years. Among them are simplicity, mobility, free/low costs, security, real-time 
immediacy, flexibility and choice, preferences specialisation and refunds (EBA, 2014). All generations have already migrated to digital channels. Mobile channels are far more likely to delight them, increase their loyalty with higher retention, repeat purchases and referrals.

Table 3. The characteristics of selected generations

\begin{tabular}{|c|c|c|c|}
\hline Criterion & Generation X & Generation Y & Generation Z \\
\hline Core values & Time & Individuality & Connectivity \\
\hline Technology & Assimilated & Integral & Digital natives \\
\hline $\begin{array}{l}\text { Preferred way } \\
\text { of communication }\end{array}$ & $\begin{array}{l}\text { Prefer personal inter- } \\
\text { actions and communi- } \\
\text { cation }\end{array}$ & $\begin{array}{l}\text { Commonly use tele- } \\
\text { phone communica- } \\
\text { tion and the Internet, } \\
\text { active on social net- } \\
\text { working sites }\end{array}$ & $\begin{array}{l}\text { Communication via } \\
\text { smartphones, active } \\
\text { on social networking } \\
\text { sites, create own doc- } \\
\text { uments and databas- } \\
\text { es, use the web to re- } \\
\text { search and network }\end{array}$ \\
\hline Communication media & Cellular phones & $\begin{array}{l}\text { The Internet, picture } \\
\text { phones, e-mails }\end{array}$ & $\begin{array}{l}\text { Smartphones, tablets } \\
\text { and other mobile } \\
\text { devices }\end{array}$ \\
\hline $\begin{array}{l}\text { Financial needs and } \\
\text { expectations }\end{array}$ & $\begin{array}{l}\text { 1) cautious and con- } \\
\text { servative } \\
\text { 2) looking for mort- } \\
\text { gages, investment } \\
\text { insurance, saving } \\
\text { programmes } \\
\text { 3) money is a means } \\
\text { to an end } \\
\text { 4) used to ingrained } \\
\text { status quo banking } \\
\text { 5) some find their } \\
\text { bank's existing mo- } \\
\text { bile interface diffi- } \\
\text { cult to work with } \\
\text { 6) display some will- } \\
\text { ingness to adopt } \\
\text { mobile banking, } \\
\text { but they lack the } \\
\text { enthusiasm } \\
\text { 7) security con- } \\
\text { cerns about new } \\
\text { technology } \\
\text { 8) declare the open- } \\
\text { ness to the idea } \\
\text { of mobile banking }\end{array}$ & $\begin{array}{l}\text { 1) earn to spend } \\
\text { 2) money is today's } \\
\text { payoff } \\
\text { 3) looking for first } \\
\text { car loans, first } \\
\text { mortgages, credit } \\
\text { cards, student loans } \\
\text { 4) half of them would } \\
\text { switch banks } \\
\text { to mobile payments } \\
\text { capability from } \\
\text { their primary bank }\end{array}$ & $\begin{array}{l}\text { 1) looking for savings } \\
\text { and payment ac- } \\
\text { counts, first credit } \\
\text { cards, student loans } \\
\text { 2) more conservative, } \\
\text { more money-ori- } \\
\text { ented, more en- } \\
\text { trepreneurial and } \\
\text { pragmatic about } \\
\text { money compared } \\
\text { to Millennials, } \\
\text { 3) elusive to tradition- } \\
\text { al financial servic- } \\
\text { es providers } \\
\text { 4) use mostly mobile } \\
\text { devices such } \\
\text { as smartphones, } \\
\text { tablets, and laptops } \\
\text { for communication } \\
\text { 5) expect everything } \\
\text { to be digital } \\
\text { 6) expect seamless } \\
\text { cross-channel } \\
\text { customer service }\end{array}$ \\
\hline
\end{tabular}

Source: authors' own elaboration based on First Data Corporation, 2010; Williams, Page, 2011; BMO Wealth Institute, 2014 
The rapid adoption of technology by consumers is changing their needs and the way they interact with banks (CFSA, 2015). Mobile channels will probably become the "first screen" through which customers interact with a bank. Banks will need to innovate to meet customers' expectations and compete with nonbank institutions. FinTechstart-ups and other non-bank financial services providers entering the banking market will create more options for customers. Banks should offer mobile apps different from every other mobile banking app to keep customers engaged and provide them with an experience similar to that of using the Amazon, Google or Apple apps (CFSA, 2015; Arnfield, 2016).

\section{The framework for including mobile technology in Banks' Business Model}

The analysis of mobile banking application along with the progressive increase of smartphone users and m-commerce development show the impressive potential of mobile technology. Banks' existing business models treated this technology as one of communication or/and distribution channels. They focused rather on selected aspects of banks' activity such as a range of products and financial needs that might be fulfilled by those products (universal bank and specialised bank), a level of service quality and its correlation with a price level (financial advisor for mass affluent customers, community bank model, discount bank model, trust operator model), as well as the nature and scope of activities and funding strategies (Capgemini, 2008; Deloitte, 2012; Thomkus, 2014; Roengpitya, Tarashev, Tsatsaronis, 2014; Ayadi et al., 2016; Framé, Vouldis, 2017). They took into account general customers' needs and expectations but did not focus on delighting them during the overall customer journey with the bank. Competing with non-bank providers will require changing the prior assumption of banks' business models and developing the ability to create exceptional, personalised value for customers.

Decreasing the consumer defection rate might be achieved by implementing three customer elements simultaneously (Symons, Wright, Ott, 2007):

1) designing the right propositions for the right customers - a task that involves identifying target segments of the market and crafting propositions and experiences to delight them,

2) delivering these propositions by focusing the entire company on them with an early and ongoing emphasis on cross-functional collaboration,

3) continually developing the capabilities to delight customers again and again. Each of these "Three D's" contributes to value for customers' creation and reinforces the others. When wielded together, they can effectively transform a bank 
into an organisation that is continually and profitably developing an individual customer's satisfaction and loyalty.

As banks play a crucial role in the economy, their business models must accommodate and balance a particular bank's aims focused on value creation, its market position and profits with the public interest focused on safety. The analysis of concurrent banks' business models and the results of other research are the basis for preparing the foundations of the framework for a customer-focused bank business model. Figure 2 presents the conceptual framework that combines the safety and regulations requirement with resources management and active interaction with customers based on the "Three D's" concept.

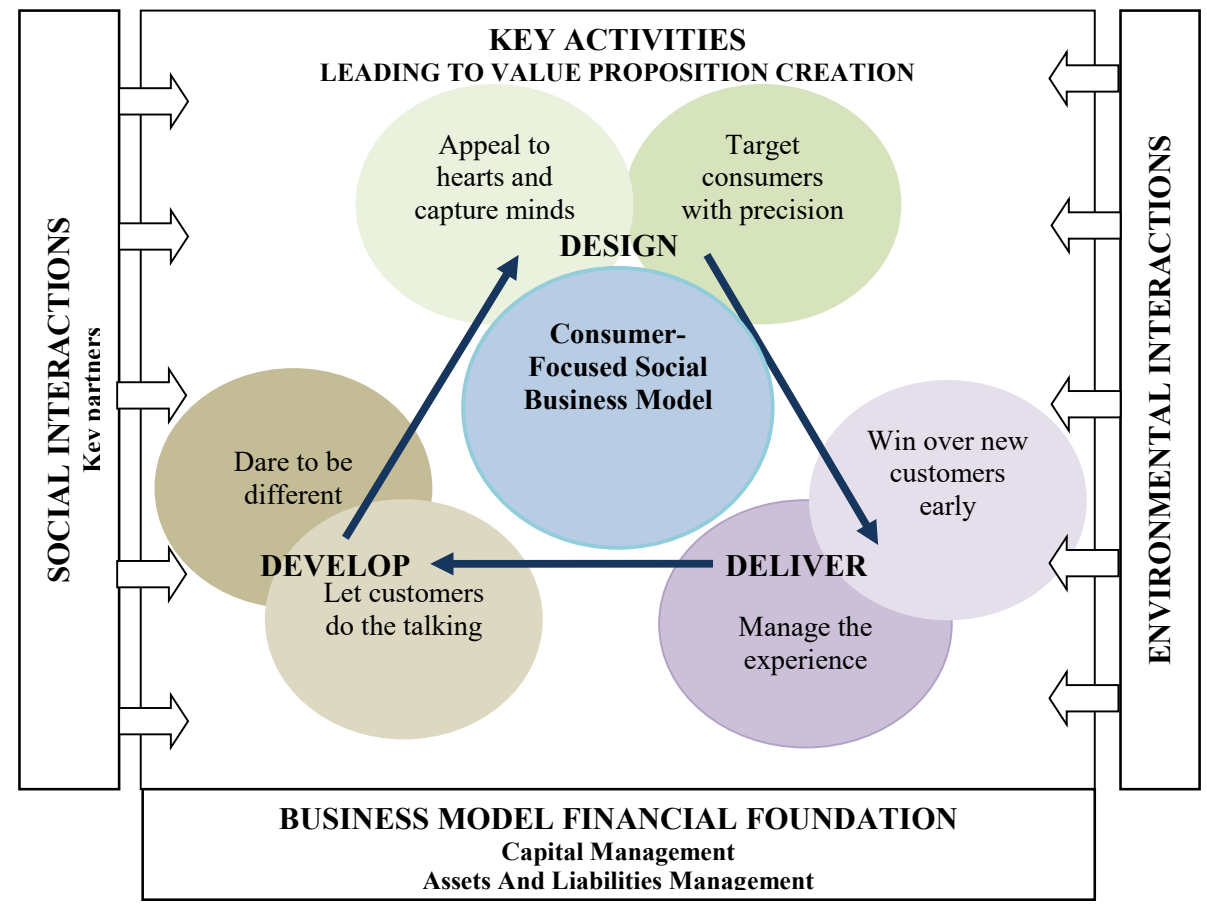

Figure 2. The Bank 3D business model canvas

Source: authors' own elaboration

Table 4 presents the relationship between the model fields, core values of different generations and possible application of mobile technology for driving customers' value.

The detailed components of a business model must be carefully crafted to capitalise the enthusiasm that new customers bring to their selection of products and provider, and allow the bank to monitor how customers are using its services and systematically track any potential problems that could cause a new customer to defect. Managing the customer relationship needs tracking 
how well the bank delivers on promises and what is the customers' experience day by day in contacts they have with each branch office or call centre. The ability to delight customers, again and again, means not only gathering customers' opinions but the use of these findings to correct shortcomings, fine-tune product and service offerings, and, by tying improvements to compensation, motivate employees. All these processes may be successfully supported by mobile technology. They should include mobile channels as part of multichannel integration (using mobile technology will help in the process of creating an optimised, seamless experience), next-generation mobile branch networks that include 'cookie-cutter' branches, innovative relationship management, with a particular focus on customers' experience and customer feedback management.

Table 4. The mobile technology as a value driver for customers' generations in banks' business models

\begin{tabular}{|c|c|l|c|}
\hline $\begin{array}{c}\text { Bank 3D } \\
\text { Business } \\
\text { Model }\end{array}$ & $\begin{array}{c}\text { Generations' } \\
\text { Values }\end{array}$ & \multicolumn{1}{c|}{ Mobile Technology Application } \\
\hline Design & & $\begin{array}{l}\text { Real-time analysis of customers' behaviour concerning: } \\
\text { 1) } \begin{array}{l}\text { time, scope of used services, location, preferred way of commu- } \\
\text { nication, }\end{array}\end{array}$ \\
2) $\begin{array}{l}\text { 2ustomers' activity in social media, } \\
\text { 3) big data analysis. }\end{array}$
\end{tabular}

Source: authors' own elaboration

The integrated business model architecture must be powered by analytics (real-time event management and others), advanced digital advisory and need-based offerings optimised by customers and channels. Additionally, banks will base building long-term relations with customers on their engagement where they spend their time (e.g.: on social media), following their personal interests, leveraging influencers, and co-creation based on increased customer intimacy. The future 
success depends on the ability to create a digital ecosystem. In such an ecosystem, banks will serve as a trust centre with an extended proposition (financial and non-financial) wherever customers leverage the power of mobile and offer m-payment services (Accenture, 2012).

The presented conceptual framework for a bank business model enabling the increase of customers' engagement could be the basis for further quantitative empirical research focused on factors that can help or interrupt using mobile technology for its development. Among different factors influencing the shape of banks' business models and their ability to create and deliver value are (Kumar et al., 2016):

1) the threat of new entrants resulting in increased competition from FinTechs and neo-banks - non-banking service providers in the form of Fintech players are causing disruption and disintermediation, often targeting discrete highly profitable segments of the banking value chain,

2) changing customer demographics and expectations that are driving the need for innovation to meet customers' demand,

3) the increasing risk of cyber threats - facing the unprecedented challenge of data breaches, banks are forced to strengthen their security and authentication systems,

4) the development of cloud services for core business activities as a key enabler of increased agility and improved cost efficiency to support banks' business strategy,

5) the need for the transformation of banks' legacy systems allowing them to drive agility, achieve better time to market, and develop competitive differentiation,

6) the development of distributed ledger technology that is expected to eliminate banks' need for managing multiple databases and reconciliation structure as well as to enhance the transpiration of transaction into the future,

7) the necessity for full integration of banks' risk management and compliance,

8) the implementation of advanced analytics to deliver insights about customers focused on detection and mitigation of risks associated with frauds,

9) financial inclusion and financial awareness.

Today's banking customers want more transparency, more simplicity and easy access. Above all, they seek a seamless experience as they move from one channel to another. Customers are interacting with multiple channels, both physical and digital. More and more, they rate banks according to the overall experience. 


\section{Conclusions}

The last decades have brought fast development of new technologies that have influenced customers' market behaviour. Compared to non-bank financial services, provider banks are perceived as traditional ones. Although they implement mobile technology and mobile applications in some fields of their market activity, their business models are still not focusing on creating, delivering and enhancing value for customers. It is high time to start to be more communicative, more customer-centric and innovative.

The literature review concerning business models, the analysis of banks' contemporary business models and mobile technology application in the retail banking market provided the foundations for preparing the proposed bank business model framework. The business model concept presented in the paper incorporates the two core aspects of banks' market activity.

The first is the ability to delight customers and deliver value during the whole customer experience. Such an ability is necessary for creating a competitive advantage and maintaining the bank's market position. Today designing and delivering value for customer is commonly considered to be one of the most important parts of creating customer loyalty. Mobile channels are thought to be more suitable for delighting customers than branch or call centre experiences and leading to increased loyalty with higher customer retention, repeat purchases and referrals. Customers increasingly expect to follow up with bank staff through digital chat, video or other real-time options, and banks actively develop them (Symons, Wright, Ott, 2007; Arnfield, 2015; 2016; Klimontowicz, Derwisz, 2016; Hes, Jílková, 2016; Vlasov, 2017; Japparova, Rupeika-Apoga, 2017). The assumed potential of mobile technology presented in the paper corresponds also to some predictions made by Deloitte, Capgemini and Accenture (Deloitte, 2012; Accenture, 2012; Martino, Schaffner, 2015; Kumar et al., 2016; Kobler, Bucherer, Schlotmann, 2016).

The second aspect is banks' social and economic responsibility that requires adequate capital, assets and liabilities management and fulfilling the regulatory requirements. The strong financial foundations for business models correspond to findings of those researchers who base their business model analysis on financial data (Roengpitya, Tarashev, Tsatsaronis, 2014; Thomkus, 2014; Ayadi et al., 2016; Framé, Vouldis, 2017)

Combining customers' engagement in the value creation process with strong financial foundations for the business model should bring benefits not only for a given bank but also for the whole economy and society. Such a complex business model framework must be precisely matched with a particular bank's specificity. In the nearest future, banks' business model must reflect changes in customers' behaviour and expectations as well as take into account new market players and they value proposals. 


\section{References}

Accenture (2012), Banking 2016. Accelerating Growth and Optimising Costs in Distribution and Marketing, Distribution and Marketing Services, https://www.accenture.com/tw-en/ /media/Accenture/Conversion-Assets/DotCom/Documents/Global/PDF/Industries_3/Accenture-Banking-2016.pdf [accessed: 2.01.2019].

Ahlqvist T., Bäck A., Halonen M., Heinonen S. (2008), Social Media Road Maps Exploring The Futures Triggered by Social Media, Edita Prima Oy, VTT Technical Research Centre of Finland, Helsinki.

Arnfield R. (2015), The Customer's Journey: Transforming the Branch Network, "ATM Marketplace", Networld Media Group, pp. 2-7.

Arnfield R. (2016), Transforming the Bank Customer Experience for the Digital Revolution, "ATM Marketplace", Networld Media Group, pp. 3-9.

Ayadi R., Groen W.P. de, Sassi I., Mathlouthi W., Rey H., Aubty O. (2016), Bank Business Monitor 2015. Europe, HEC Montreal, International Research Centre on Cooperative Finance, Montreal.

Ballon P. (2007), Business Modelling Revisited: The Configuration of Control and Value, "The Journal of Policy, Regulation and Strategy for Telecommunications, Information and Media", vol. 9, no. 5, pp. 6-19.

Birkinshaw J., Ansari S. (2015), Understanding management models: going beyond "what" and "why" to "how" work gets done in organizations, [in:] N. J. Foss, T. Saebi (eds.), Business Model Innovation: the Organizational Dimension, Oxford University Press, Oxford, pp. 85-103.

Blount Y. (2010), Employee Management and Service Provision: A Conceptual Framework, "Information Technology and People", vol. 24, no. 2, pp. 134-157.

BMO Wealth Institute (2014), Wealth Generation. The Financial Challenges for Generations $X \& Y$, BMP Wealth Institute Report, Canadian Edition, http://www.bmo.com/wealthinstitute [accessed: 2.01.2019].

Capgemini (2008), World Retail Banking Report, pp. 45-46, https://www.capgemini.com/resources/world_retail_banking_report_2008/ [accessed: 30.12.2018].

Casadesus-Masanel R. School Working Paper", http://ssrn.com/abstract=1115201 [accessed: 30.12 .2018 ] or http://dx.doi.org/10.2139/ssrn.1115201.

CFSA (2015), Top 10 Trends in Banking in 2016, Capgemini Financial Services Analysis, pp. 4-5, http://www.capgemini.com [accessed: 15.06.2016].

Delafrooz N., Taleghani M., Taghineghad M. (2013), The Impact of Service Innovation on Customer Satisfaction, "International Journal of Marketing and Technology", vol. 3, no. 5, pp. 127-144.

Deloitte (2012), Wyniki badania doświadczenia klienta $w$ relacji z bankami w Polsce. Europejski Kongres Finansowy, https://www.efcongress.com/sites/default/files/m.dubno_wynikibadaniadoswiadczeniaklienta.pdf [accessed: 31.01.2019].

Demil B., Lecocq X., Ricart J.E., Zott C. (2015), Introduction to the SEJ Special Issue on business models: business models within the domain of strategic entrepreneurship, "Strategic Entrepreneurship Journal", vol. 9, issue 1, pp. 1-11.

Dubosson-Torbay M., Osterwalder A., Pigneur Y. (2002), E-Business Model Design, Classification, and Measurements, "Thunderbird International Business Review", vol. 44, no. 1, pp. 5-23.

Durkin M., Mulholland G., McCartan A. (2015), A Socio-Technical Perspective on Social Media Adoption: A Case From Retail Banking, "International Journal of Bank Marketing", vol. 33, no. 7, pp. 944-962.

EBA (2014), Opinion Paper on Next Generation Alternative Retail Payment (e-AP) User Requirements, Euro Banking Association, Paris. 
Ernst \& Young (2015), Imagining the Digital future. How digital themes are transforming companies across industries, http://www.ey.com/Publication/vwLUAssets/EY-imagining-the-digital-future/\$FILE/EY-imagining-the-digital-future.pdf [accessed: 30.09.2018].

Evans S., Vladimirova D., Holgado M., VanFossen K., Yang M., Silva E.A., Barlow C.Y. (2017), Business Model Innovation for Sustainability: Towards a Unified Perspective for Creation of Sustainable Business Models, "Business Strategy and the Environment", vol. 26, pp. 597-608.

First Data Corporation (2010), Tapping Into Generation Y: Nine Ways Community Financial Institutions Can Use Technology to Capture Young Customers, A First Data White Paper.

Framé M., Vouldis A. (2017), Business models of the banks in the euro area, "Working Papers Series", European Central Bank, http://dx.doi.org/10.2866/386225.

Hanna R., Rohm A., Crittenden V.L. (2011), We're all connected: The power of the social media ecosystem, "Elsevier Business Horizons", vol. 54, pp. 265-273.

Hes A., Jílková P. (2016), Position of Low-Cost Banks on the Financial Market in the Czech Republic, "European Research Studies", vol. XIX, issue 4, pp. 42-52.

Honebein P. C., Cammarano R.F. (2006), Customers at Work, "Marketing Management", vol. 15, no. 8 , pp. 26-31.

Jansen W., Steenbakker W., Jägers, H. (2017), New Business Models for the Knowledge Economy, Routledge, Taylor \& Francis Group, London-New York.

Japparova I., Rupeika-Apoga R. (2017), Banking Business Models of the Digital Future: The Case of Latvia, "European Research Studies", vol. XX, issue 3A, pp. 846-860.

Johnson M.W., Christensen C.C., Kagermann H. (2008), Reinventing your business model, "Harvard Business Review", vol. 86, no. 12, pp. 50-59.

Kaplan A.M., Haenlein M. (2010), Users of The World, Unite! The Challenges and Opportunities of Social Media, "Business horizons", vol. 53, no. 1, pp. 59-68.

Klimontowicz M., Derwisz K. (2016), Mobile Technology on Retail Banking Market, European Financial Systems 2016. Proceedings of the $13^{\text {th }}$ International Scientific Conference, Masaryk University, Brno.

Klimontowicz M., Harasim J. (2017), Socio-Demographic Factors Influencing Bank's Business Model Development, [in:] G. Hofbauer, M. Klimontowicz (eds.), Challenges, Research and Perspectives 2016: Europe in a Changing World, Uni-edition, Berlin, pp. 24-36.

Kobler D., Bucherer S., Schlotmann J. (2016), Banking business model of the future, https:// www2.deloitte.com/lu/en/pages/investment-management/articles/banking-business-models-of-the-future.html [accessed: 30.09.2018].

Kumar A., Saxena A., Suvarna V.K., Ravat V. (2016), Top 10 Trends in Banking in 2016, Capgemini, https://www.capgemini.com/wp-content/uploads/2017/07/banking_top_10_trends_2016. pdf [accessed: 15.04.2017].

Magretta J. (2002), Why Business Models Matter, "Harvard Business Review", vol. 80, no. 5, p. 86-92, 133.

Martino P., Schaffner J. (2015), Impact of digital transformation on banking operating models, "Capgemini Inside Magazine", issue 8, https:/www2.deloitte.com/content/dam/Deloitte/lu/Documents/financial-services/Banking/lu-impact-digital-transformation-banking-operating-models.pdf [accessed: 30.09 .2018$]$.

Massa L., Tucci C.L., Afuah A. (2017), A critical assessment of business model research, "Academy of Management Annals", vol. 11, no. 1, pp. 73-104.

Mayfield A. (2008), What is Social Media?, e-book from iCrossing.

Morris M., Schindehutte M., Allen J. (2005), The entrepreneur's business model: Toward a unified perspective, "Journal of Business Research", vol. 58, pp. 726-735. 
Murray L., Durkin M., Worthington S., Clark V. (2014), From Discrete to Relational Tweeting: on The Integration of Twitter into Relationship Banking, "Journal of Financial Services Marketing", vol. 19, no. 4, pp. 277-290.

Nosowski A. (2010), Bankowe modele biznesowe - ewolucja czy innowacja (Banks' Business Models - Evolution or Innovation), "Annales Universitatis Mariae Curie-Skłodowska. Sectio H", vol. 44, no. 2, pp. 157-167.

Nosowski A. (2012), Modele, strategie i metody zarzadzania w instytucjach kredytowych (Models, Strategies and Management Methods in Credit Institutions), [in:] A. Gospodarowicz, A. Nosowski (eds.), Zarzadzanie Instytucjami kredytowymi (The Management of Credit Institutions), Wydawnictwo C.H. Beck, Warszawa, pp. 36-126.

Osterwalder A, Pigneur Y. (2005), Clarifying Business Models: Origins, Present, and Future of The Concept, "Communications of AIS", vol. 16, pp. 1-25.

Papagiannidis S., Bourlakis M. (2015), Social Media: A Revolution in Communication, "Technological Forecasting and Social Change", vol. 95, pp. 1-2.

Persson A. (2013), Profitable Customer Management: Reducing Costs By Influencing Customer Behavior, "European Journal of Marketing”, vol. 47, no. 5/6, pp. 857-876.

Priem R.L., Wenzel M., Koch J. (2018), Demand-side strategy and business models: Putting value creation for consumers center stage, "Long Range Planning", vol. 51, pp. 22-31.

Pyka I. (ed.) (2013), Bankowość komercyjna (Commercial banking), Wydawnictwo Uniwersytetu Ekonomicznego w Katowicach, Katowice.

Ritter T. (2014), Alignment Squared: Driving Competitiveness and Growth through Business Model Excellence, CBS Competitive Platform, Copenhagen.

Roengpitya R., Tarashev N., Tsatsaronis K. (2014), Bank business models, "BIS Quarterly Review”, December, pp. 55-65.

Saebi T., Foss N.J. (2014), Business Models for Open Innovation: Matching Heterogenous Open Innovation Strategies with Business Model Dimensions, "European Management Journal", https://research.cbs.dk/en/publications/business-models-for-open-innovation-matching-heterogeneous-open-i-2 [accessed: 30.09.2018].

Santos J., Spector B., Heyden L. van der (2009), Toward a Theory of Business Model Innovation with Incumbent Firms, Working paper no. 2009/16/ EFE/ST/TOM, INSEAD, Fontainebleau, France.

Shafer M., Smith H.J., Linder J. (2005), The power of business models, "Business Horizons", vol. 48, pp. 199-207.

Symons M., Wright T., Ott J. (2007), The Customer-Led Bank: How to Retain Customers and Boost Top-Line Growth, "Journal of Business Strategy", vol. 28, no. 6, pp. 4-12.

Teece D.J. (2010), Business models, business strategy and innovation, "Long Range Planning", vol. 43, issue 2-3, pp. 172-194.

Teece D.J. (2018), Business models and dynamic capabilities, "Long Range Planning", vol. 51, pp. $40-49$.

Thalassinos I.E. (2008), Trends and Developments in the European Financial Sector, "European Financial and Accounting Journal", vol. 3, issue 3, pp. 44-61.

Thalassinos I.E., Venediktova B., Staneva-Petkova D. (2013), Way of Banking Development Abroad: Branches or Subsidiaries, "International Journal of Economics and Business Administration", vol. 1, issue 3, pp. 69-78.

Thomkus M. (2014), Identifying Business Models of Banks: Analysis of Biggest Banks from Europe and United States of America. Cluster analysis of business model identifying variables, Aarhus University, Department of Economics and Business, Aarhus.

Vlasov A.V. (2017), The Evolution of E-Money, "European Research Studies", vol. XX, issue 1, pp. 215-224. 
Weinberg B.D., Pehlivan E. (2011), Social Spending: Managing The Social Media Mix, "Elsevier Business Horizons", vol. 54, pp. 275-282.

Wieland H., Vargo S.L., Hartmann N.N. (2017), Business models as service strategy, "Journal of the Academy of Marketing Science", vol. 45, pp. 925-943, http://dx.doi.org/10.1007/ s11747-017-0531-z.

Williams K.C., Page A.R. (2011), Marketing to Generation, "Journal of Behavioral Studies in Business", vol. 3, April, http://www.aabri.com/jbsb.html [accessed: 30.09.2018].

Wirtz B.W., Pistoia A., Ullrich S., Gottel V. (2016), Business models: origin, development and future research perspectives, "Long Range Planning", vol. 49, issue 1, pp. 36-54.

Zott C., Amit R. (2008), The Fit Between Product Market Strategy and Business Model: Implications for Firm Performance, "Strategic Management Journal", vol. 29, no. 1, pp. 1-26.

Zott C., Amit R. (2010), Business Model Design: An Activity System Perspective, Long Range Planning, "Business Models", vol. 43, no. 2-3, pp. 216-226.

Zott C., Amit R., Massa L. (2011), The Business Model: Recent Developments and Future Research, "Journal of Management", vol. 37, no. 4, pp. 1019-1042.

\section{Technologia mobilna w modelach biznesowych banków}

Streszczenie: Zmiany, które dokonały się na rynku bankowym na przestrzeni ostatnich kilku dekad, stanowią dla banków źródło nowych wyzwań. Rozwój technologii mobilnych ma znaczący wpływ na wiele obszarów ludzkich działań, w tym zachowania na rynku usług bankowych. Upowszechnienie technologii mobilnej zmieniło zarówno sposób przekazywania informacji i komunikacji, jak i zachowania nabywcze klientów. Wszystkie te zmiany powinny być uwzględnianie w procesie poszukiwania źródeł przewagi konkurencyjnej i projektowania modelu biznesowego banku.

Celem artykułu jest zaproponowanie założeń modelu biznesowego banku uwzględniających technologię mobilną jako narzędzie dostarczania wartości dla klientów i źródło przewagi konkurencyjnej. Założenia te zostały opracowane na podstawie studiów literaturowych. W artykule przedstawiono analizę modeli biznesowych wykorzystywanych przez banki, dostarczanych w ramach tych modeli propozycji wartości dla klientów oraz ich dopasowania do potrzeb i oczekiwań odbiorców. Analizę podsumowują przesłanki dotyczące wykorzystania technologii mobilnej do dalszego rozwoju modeli biznesowych banków, sformułowane z perspektywy kreowania i dostarczania wartości dla klientów.

Słowa kluczowe: model biznesowy banku, technologia mobilna, wartość dla klienta, innowacje bankowe

JEL: G21, O33, D14 


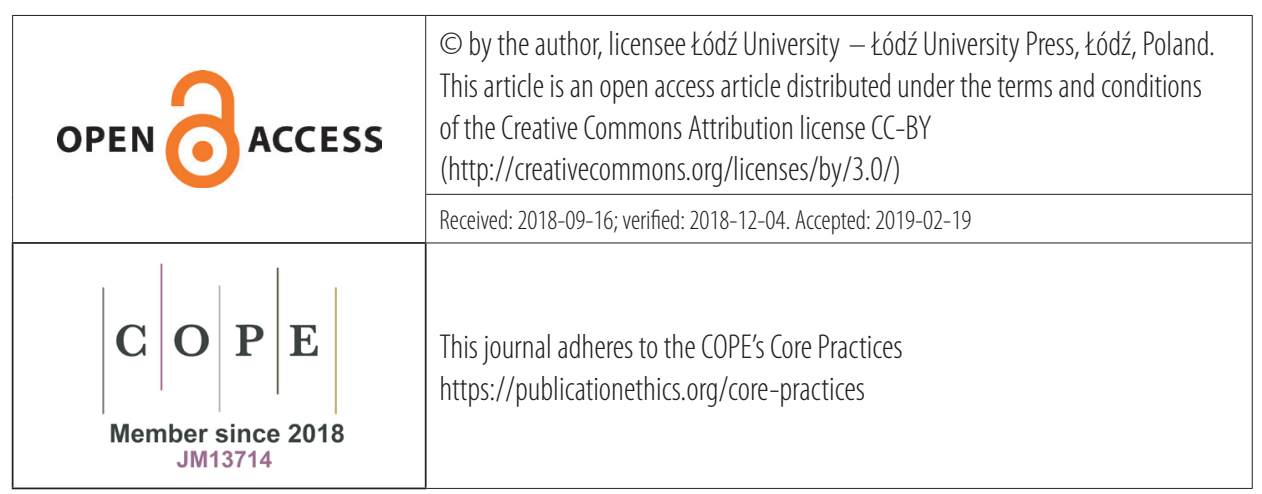

